\title{
Sources of shared variability of the carcass and non-carcass components in Pekin ducklings
}

\author{
Karima A. SHAHIN* \\ Department of Animal Production, Faculty of Agriculture, Ain Shams University, \\ P.O. Box 68, Hadayek Shoubra, 11241 Cairo, Egypt
}

(Received 25 May 1998; accepted 28 September 1999)

\begin{abstract}
A factor analysis with a vari max rotation was applied to 5 highly intercorrelated slaughter traits on 430 Pekin ducks to disclose the main sources of shared variability and deduce the factors that describe carcass and edible offal 'non-carcass' traits. Carcass and edible offal traits appeared to be controlled by common and unique factors. The communalities ranged from 0.57 (gizzard) to 0.92 (abdominal fat) and the uniqueness (special size factors) complement to 1. Findings indicated the most of the common variability (72.9\%) in slaughter traits could be accounted for by factors representing general size and abdominal fat factors. Independent slaughter traits 'general size and abdominal fat' derived from factor analysis accounted for $77.8 \%$ of the variation in live body weight.
\end{abstract}

factor analysis / Pekin ducks / multicollinearity / carcass weight variations / abdominal fat weight variations / visceral variation

Résumé - Sources de variabilité commune des composants de la carcasse et des abats chez le canard Pékin. Une analyse factorielle utilisant une rotation varimax a été appliquée à 5 variables d'abattage (poids de la carcasse, du cœur, du foie, du gésier et du gras abdominal) sur 430 canards Pékin pour identifier les principales sources de variabilité commune et déterminer les facteurs qui décrivent les caractéristiques de la carcasse et des abats comestibles. Les caractéristiques de carcasse et des abats semblent contrôlées par des facteurs communs et des facteurs spécifiques. Les parts de variance dues aux deux facteurs communs sont comprises entre 0,57 (gésier) et 0,92 (gras abdominal) et les facteurs uniques font le complément à 1 pour chaque caractère. Les résultats indiquent que la majeure partie de la variabilité commune $(72,9 \%)$ des caractéristiques d'abattage peut être expliquée par des facteurs représentant d'une part la taille générale et d'autre part le gras abdominal. Les caractéristiques d'abattage (taille générale et gras abdominal) dérivées de l'analyse factorielle comptent pour $77,8 \%$ dans la variation du poids vif corporel.

analyse factorielle / canard Pékin / multicollinéarité / variation du poids de la carcasse / variation du gras abdominal / variation du poids des abats

* Correspondence and reprints

Tel.: 20244417 11; fax: 2024444460 


\section{INTRODUCTION}

A quantitative estimate of carcass and non-carcass components and their variability are essential to livestock and poultry producers, meat industry and scientist. Since these traits are intercorrelated both genetically and phenotypically in chickens $[3,13$, 16], in turkeys [2] and in ducks [17, 22, 23] the analysis of these traits should address interdependence among independent variables. Independent factor scores derived from factor analysis have been used advantageously as predictors of total carcass muscle and bone traits in ducks [22] and in quail [24] and as a selection criterion for genetic improvement of muscle weight distribution in ducks [23].

Research data depicting the relationship between carcass and non-carcass components and join phenotypic variability for these traits in Pekin ducklings are lacking in the literature. Therefore, this study was designed to identify the main sources of shared variability and deduce factors that describe slaughter traits (carcass, heart, liver, gizzard, abdominal fat) in Pekin ducklings.

\section{MATERIALS AND METHODS}

Four hundred and thirty (equal number of males and females) Pekin ducklings, approximately $1700 \mathrm{~g}$ in live weight and 10 weeks of age from the experimental poultry farm of the Faculty of Agriculture, Tanta University, Egypt were used in the present study. These ducklings produced from three consecutive hatches secured throughout March to May. The ducklings were housed in temperature controlled battery brooders for the first two weeks, after which they were reared on a litter-floored pens under uniform condition. All ducklings received feed and water ad libitum and the diet containing approximately $22 \%$ of protein and a metabolizable energy of $2900 \mathrm{kcal} / \mathrm{kg}$, from hatching to 10 weeks. At 10 weeks of age, the birds were starved for $12 \mathrm{~h}$ with access to water and then slaughtered by severing the carotid artery and jugular veins. After dry plucking, the birds were eviscerated, the feet and shanks were removed at the tibio-tarsus joint and the head at the atlantooccipital articulation. The viscera were removed as for the usual dressing of poultry carcasses. The heart, liver (minus the gall bladder) and empty skinned gizzard were trimmed of extraneous tissue and weighed individually and their sum of weights 'giblets' was taken. Abdominal fat including fat surrounding gizzard and fat trimmed from alimentary tract was removed and weighed. Carcass yield 'dressing percentage' is obtained by expressing the dressed carcass weight (without giblets) as a percentage of live body weight. The data from males and females are combined since the two data dispersion matrices did not differ significantly (untabulated).

\subsection{Statistical analysis}

The data were subjected to factor analysis procedure [20]. The main source of shared variation among correlated slaughter variables $(p)$ was expressed in terms of fewer mutually uncorrelated common factors $F_{1}, \ldots, F_{q}$ (where $q<p$ ) than the original variables [6]. The general model used for factor analysis has been described by Shahin [22, 23].

\section{RESULTS AND DISCUSSION}

\subsection{Original 'non-independent' variables}

Table I presents the means, standard deviations and coefficient of variation for live weight and slaughter traits. Body weight averaged $1700 \mathrm{~g}$ and ranged from 1000 to 2596 g. Carcass weight averaged $1090.9 \mathrm{~g}$, which was $63.5 \%$ of live body weight and giblets as a percentage of live weight averaged 7.0. The average dressing percentage 
Table I. Means, standard deviations (S.D.) and coefficient of variation (CV \%) for live weight, carcass weight and non-carcass component taits in Pekin ducklings.

\begin{tabular}{lrrr}
\hline & Mean & S.D. & CV\% \\
\hline Live weight $(\mathrm{g})$ & 1700.0 & 307.2 & 18.1 \\
Carcass weight $(\mathrm{g})$ & 1090.9 & 281.5 & 25.8 \\
Heart weight $(\mathrm{g})$ & 11.8 & 2.2 & 18.6 \\
Liver weight $(\mathrm{g})$ & 42.2 & 10.4 & 24.6 \\
Gizzard weight $(\mathrm{g})$ & 63.3 & 10.0 & 15.8 \\
Abdominal fat weight $(\mathrm{g})$ & 8.3 & 5.5 & 66.3 \\
Giblets weight $(\mathrm{g})$ & 117.2 & 18.9 & 16.1 \\
\% of Live weight & & & \\
$\quad$ Carcass & & & \\
$\quad$ Heart & 63.5 & 6.4 & 10.1 \\
Liver & 0.7 & 0.1 & 14.3 \\
Gizzard & 2.5 & 0.5 & 20.0 \\
Abdominal fat & 3.8 & 0.7 & 18.4 \\
Giblets & 0.5 & 0.3 & 60.0 \\
\hline
\end{tabular}

${ }^{1}$ without giblets.

reported in this study was higher than that reported $(60 \%)$ by Wilson [27, 28], Koci et al. [10], Baumgartner et al. [1] and similar to those reported by Kamar and Yamani [9], Hetzel [8], Pingel [15] for Pekin ducklings. In Muscovy ducklings, Ricard [17] reported a range of 60 to $64 \%$ for eviscerated carcass weight expressed as a percentage of live body weight. In geese, Stevenson [25] estimated dressing percentage as 62.9 and $63.4 \%$ for females and males, respectively. The heart, liver, gizzard and abdominal fat constituted $0.7,2.5,3.8$ and $0.5 \%$ of live body weight respectively (Tab. I).

Coefficient of variation ranged from $15.8 \%$ for gizzard weight to $66.3 \%$ for abdominal fat weight (Tab. I). Saleh et al. [21] estimated the coefficient of variation for the amount of abdominal fat as $42.3 \%$. In a literature review by Leenstra [11] the coefficient of variation of the abdominal fat weight of broiler reared in the same environment varied from 24 to $47 \%$. The large variability of this trait along with its high heritability offers favourable prospects for selection against this trait [12].

\subsection{Their relationship with each other and with live body weight}

Live body weight was positively correlated with carcass weight and non-carcass components (Tab. II). The correlation was lowest ( $r=0.47)$ with abdominal fat weight and highest $(r=0.94)$ with carcass weight . In broiler chickens, the correlation coefficient between live body weight and abdominal fat weight was 0.50 [26], and 0.49 and 0.53 for males and females, respectively [4]. Also, Leenstra et al. [12] estimated the correlation between live body weight and abdominal fat weight as 0.46 . Weight of carcass and non-carcass components were positively intercorrelated. Similar findings have been reported in chickens $[3,5,13$, $18]$ in turkeys [2] and in ducks [14, 17].

\subsection{Varimax rotated 'independent' factors. Their interpretation}

Two common factors have been identified, contributing to $72.9 \%$ of the variability 
Table II. Coefficients of correlation between variables in Pekin ducklings.

\begin{tabular}{|c|c|c|c|c|c|c|}
\hline & Live weight & $\mathrm{CW}$ & HW & $\mathrm{LW}$ & GW & AFW \\
\hline \multicolumn{7}{|l|}{ Live weight } \\
\hline Carcass weight (CW) & 0.94 & & & & & \\
\hline Heart weight (HW) & 0.75 & 0.77 & & & & \\
\hline Liver weight (LW) & 0.54 & 0.51 & 0.52 & & & \\
\hline Gizzard weight (GW) & 0.48 & 0.42 & 0.47 & 0.47 & & \\
\hline Abdominal fat weight (AFW) & 0.47 & 0.42 & 0.32 & 0.23 & 0.24 & \\
\hline
\end{tabular}

Table III. Explained variation associated with rotated factor analysis along with communalities and unique factor for each variable. Correlation between factor score coefficients and original variables in Pekin ducklings.

\begin{tabular}{lcccc}
\hline & \multicolumn{2}{c}{ Rotated Common Factors } & Communalities & Unique factor \\
\cline { 2 - 3 } & I & II & & \\
\hline Carcass weight & 0.717 & 0.493 & 0.756 & 0.244 \\
Heart weight & 0.790 & 0.344 & 0.742 & 0.258 \\
Liver weight & 0.811 & 0.056 & 0.661 & 0.339 \\
Gizzard weight & 0.756 & 0.052 & 0.574 & 0.426 \\
Abdominal fat weight & 0.108 & 0.948 & 0.919 & 0.081 \\
\% of variance & 56.1 & 16.8 & & \\
Description & General & Abdominal & & \\
& size & fat & \\
\hline
\end{tabular}

of the original 5 variables, leaving $27.1 \%$ to the 5 'special' factors (Tab. III and Fig. 1).

The first factor (I) ('general size') is characterized by high positive loadings (factorvariate correlations) on all slaughter traits other than abdominal fat. The liver weight had the highest loadings, followed by the heart weight, gizzard weight and carcass weight. This factor accounted for $56.1 \%$ of the variation in the original variables. The percentage of total variance associated with 'general size' (56\%) in the present study was lower than those reported by Ricard and Rouvier [18,19] (74\% for Bresse Pile cockerels and $64 \%$ for the males and 60 for the females for the Cornish type chickens). These authors used principal component analysis. Differences in the relative importance of the general size factor could be related to differences in genetic adaptation to physiological needs [7]. They are also, more likely, related to different method used and to different traits analyzed.

The second factor (II) ('abdominal fat)' giving relatively high weight to abdominal fat accounted for an additional $16.8 \%$ of the total variation. Abdominal fat had the highest loadings on it followed by carcass weight. Ricard and Rouvier [18] working with chickens found that the second principal component is associated with variation in weight of abdominal fat, which accounted for $8.8 \%$ and $10.6 \%$ of the total phenotypic and genetic variation, respectively in slaughter traits. This factor is 
Figure 1. Correlation between factor score coefficients (F1, general size and $\mathrm{F} 2$, abdominal fat) and original carcass and non-carcass components in Pekin ducklings.

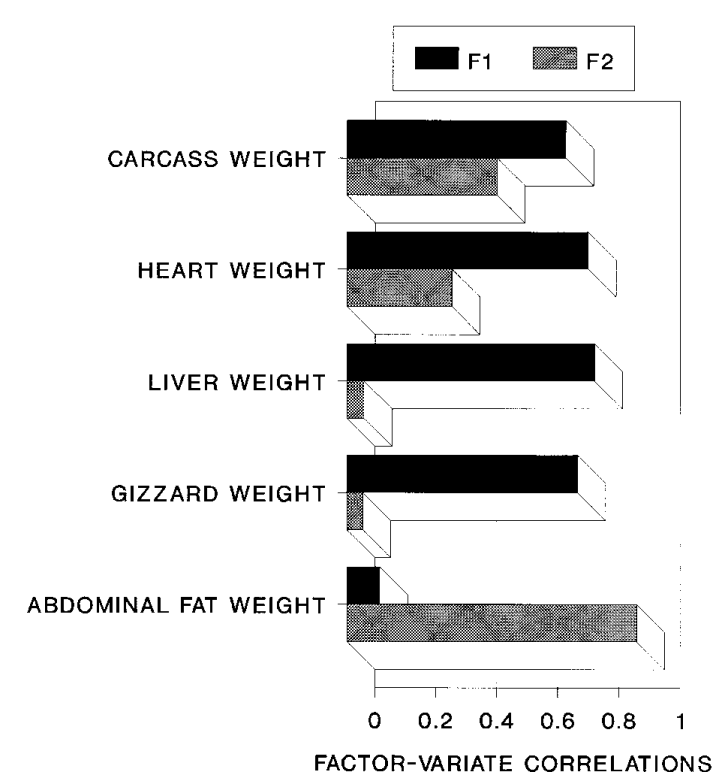

chief function of the gizzard 'muscular stomach' is to grind and mix of feed in preparation for digestion. The relatively high proportion of the unique variance for gizzard could be related to different functional needs placed on it.

In conclusion, factor analysis technique explores the interdependence in the original 5 slaughter traits by analyzing them simultaneously rather than individually and it is useful in summarizing and explaining the correlations and covariances among these interdependence traits in terms of two interpretable common factors.

\section{REFERENCES}

[1] Baumgartner J., Kočíová E., Horváthová V., Pour M., Palanská O., Konceková Z., Carcass and nutritive characteristics of Pekin, small white and Muscovy ducks and, their crosses, in: 7th International Symposium on Actual Problems of Avian Genetics, Smolenice, Czechoslovakia, 1987, pp. 163-167.

[2] Brake J., Havenstein G.B., Ferket P.R., Rives D.V., Giesbrecht F.G., Relationship of sex, strain, and body weight to carcass yield and offal production in turkeys, Poult. Sci. 74 (1995) 161-168. 
[3] Brake J., Havenstein G.B., Scheideler S.E., Ferket P.R., Rives D.V., Relationship of sex, age, and body weight to broiler carcass yield and offal production, Poult. Sci. 72 (1993) 1137-1145.

[4] Becker W.A., Spencer J.V., Mirosh L.W., Verstrate J.A., Abdominal and carcass fat in five broiler strains, Poult. Sci. 60 (1981) 693-697.

[5] Daghir N.J., Pellet P.L., Influence of breed, age and body weight on organ weight in the chickens, Br. Poult. Sci. 8 (1967) 183-191.

[6] Darton R.A., Rotation in factor analysis, The Statistician 29 (1980) 167-194.

[7] Goss R.J., Physiological adaptations of growth, Comp. Anim. Nutr. 4 (1981) 1-32.

[8] Hetzel D.J.S., The growth and carcass characteristics of crosses between Alabio and Tegal ducks and Muscovy and Pekin drakes, Br. Poult. Sci. 24 (1983) 555-563.

[9] Kamar G.A.R., Yamani K.A. Studies on duck organs, glands and meat production, Egypt J. Anim. Prod. 15 (1975) 77-94.

[10] Koci E., Baumgartner J., Illes V., Palanska O., Carcass and nutritive value of the Small White broiler duck and its crosses, Arch. Geflügelk. 46 (1982) 157-161.

[11] Leenstra F.R., Influence of diet and genotype on carcass quality in poultry, and their consequences for selection, in: Haresign W., Cole D.J.A. (Eds.), Recent advances in animal nutrition, Butterworths, London, England, 1984, pp. 3-16.

[12] Leenstra F.R., Vereijken P.F.G., Pit R., Fat deposition in broiler sire strain. 1. Phenotypic and genetic variation in, and correlations between, abdominal fat, body weight, and feed conversion, Poult. Sci. 65 (1986) 1225-1235.

[13] Mallard J., Douaire M., Strategies of selection for leanness in meat production, in: Leclercq B., Whitehead C.C. (Eds.), Leanness in domestic birds, Genetic, metabolic and hormonal aspects, Tiptree, Essex, UK, Butterworth \& Co, 1987, pp. 3-23.

[14] Pilla A.M., Possibility of genetic improvement in the Muscovy ducks, Annali dell'Istituto Spermentale per la Zootecnia 7 (1974) 165-174.

[15] Pingel H., Genetics of growth and meat production in waterfowl, in: Crawford R.D. (Ed.), Poultry Breeding and Genetics, Elsevier Amsterdam, Oxford, New York, Tokyo, 1990, pp. 691-704.
[16] Reeder L.I., Muir W.M., Use of organ weights as indicator variables to aid in a sib selection program to reduce carcass fat, Poult. Sci. 64 (1985) 167 (Abstract)

[17] Ricard F.H., Caractérisation anatomique de la carcasse de la canette de barbarie (Cairina moschata L.), Ann. Zootech. 36 (1987) 109-120.

[18] Ricard F.H., Rouvier R., Étude de la composition anatomique du poulet. I. Variabilité de la répartition des différentes parties corporelles chez des coquelets « Bresse-Pile », Ann. Zootech. 16 (1967) 23-39.

[19] Ricard F.H., Rouvier R., Étude de la composition anatomique du poulet. III. Variabilité de la répartition des parties corporelles dans une souche de type Cornish, Ann. Génét. Sél. Anim. 1 (1969) 151-165.

[20] SAS (1988) SAS User's Guide, Statistical Analysis System Institute, Inc., Cary, NC, USA.

[21] Saleh K., Shahin K.A., El Hakim A., Effects of sire and hatch on performance and carcass traits of Pekin ducklings, Egypt Poult. Sci. 7 (1987) 85-94.

[22] Shahin K.A., Analysis of muscle and bone weight variations in an Egyptian strain of Pekin ducklings, Ann. Zootech. 45 (1996) 173-184.

[23] Shahin K.A., Selection indexes using live measurements or their varimax rotated factors for improving meat weight distribution - Application on carcasses of Pekin ducks, Arch. Geflügelk. 60 (1996) 103-108.

[24] Shahin K.A., Sources of shared variability in muscle and bone weight distribution and estimation of carcass meatiness and bone utilizing orthogonal carcass traits derived from factor analysis in Japanese quail, Ann. Zootech. 46 (1997) 175-183.

[25] Stevenson M.H., Effects of diets of varying energy concentrations on the growth and carcass composition of geese, Br. Poult. Sci. 26 (1985) 493-504

[26] Van Middelkoop J.H., Kuit A.R., Zegwaard A., Genetic factors in broiler fat deposition, in: Proceedings of the 12th Poultry Science Symposium, Edinburgh, Br. Poult. Sci., 1977, pp. 131-143.

[27] Wilson B.J., Growth of ducklings fed on diets containing field beans (Vicia Faba L. ), Br. Poult. Sci. 13 (1972) 405-409.

[28] Wilson B.J., Yield of raw and cooked components from table ducklings carcasses, Br. Poult. Sci. 13 (1972) 415-417 (Research note). 